\title{
SERUM $\beta$-LIPOPROTEIN LEVELS IN HEALTH AND DISEASE, AS DETERMINED BY THE NEPHELOMETRIC METHOD WITH AMYLOPECTIN SULFATE AS REAGENT *
}

\author{
By PETER BERNFELD, C. D. BONNER $\dagger$ ANd B. J. BERKELEY \\ (From the Bio-Research Institute, Cambridge, Mass.)
}

(Submitted for publication June 28, 1960; accepted August 2, 1960)

An elevation of certain serum lipoproteins in atherosclerosis has first been described by Gofman and co-workers (1). Extensive studies of the giant serum lipoprotein molecules and of their role in atherosclerosis have subsequently been carried out by these authors, using the analytical ultracentrifuge as a tool (2-5). Their results showed a statistically significant increase of certain low density lipoprotein fractions in patients and in experimental animals with atherosclerosis. Similar findings have been reported by Barr, Russ and Eder (6), using the technique of fractional protein precipitation.

Both methods of serum $\beta$-lipoprotein determination are time consuming, require intricate and costly equipment, and may necessitate specially trained personnel. In the search for simpler and quicker methods, particularly in view of the desirability of screening large human populations, the specific interaction of serum $\beta$-lipoprotein with macromolecular polyanions has provided a novel principle for the assay of this serum protein. The study of the lipoprotein-polyanion interaction has shown that these two components are capable of forming several types of complexes of varying solubility and affinity $(7,8)$, and that the solubility of the complexes is governed by the chemical and physicochemical nature of the polyanion (9). Amylopectin sulfate has been found to produce a highly insoluble complex with human serum $\beta$-lipoprotein (10), and nephelometric evaluation of the concentration of this complex has been applied to the quantitative determination of $\beta$-lipoprotein (11). Other macromolecular polyanions have been suggested for the same purpose, such as heparin in the presence of calcium (12), dextran sulfate $(13,14)$, and carrageenin $(15)$.

* This investigation was supported in part by Research Grant H-3849 from the National Institutes of Health, Bethesda, Md., and by a grant from the Life Insurance Medical Research Fund.

$\dagger$ Holy Ghost Hospital, Cảmbridge, Mass.
Recent studies dealing with the influence of the chemical and physicochemical nature of macromolecular polyanions and their interaction with human serum $\beta$-lipoprotein (16) have shown that a variation in the molecular weight of the polyanion changes the solubility of the complex and, hence, modifies the results of lipoprotein analysis. For the procedure of determining this protein, only those polysaccharide sulfates appear to be suitable, therefore, which can be easily obtained at a highly reproducible degree of polymerization, without requiring prior hydrolysis or fractionation. The sulfation of amylopectin extracted from cornstarch by the method of Schoch (17) appears to provide a highly reliable reagent which fulfills all these requirements and which, in addition, has been found to have the advantage of yielding more insoluble complexes with human serum $\beta$-lipoproteins than practically any other polyanion (16).

The present paper emphasizes the reproducibility of the data for $\beta$-lipoprotein obtained with amylopectin sulfate as a reagent, provides clinical findings on a large population of over 2,000 subjects, and demonstrates the practical applicability of this extremely simple and rapid method, in particular for large-scale screening programs.

\section{FXPERIMENTAL}

Method. The procedure for lipoprotein determination described previously was followed (11). Aliquots of 0.1 $\mathrm{ml}$ of serum were diluted to $25 \mathrm{ml}$ with "Tris" buffer, $\mathrm{pH}$ 8.6, ionic strength 0.05 . After nephelometric determination of the light scattering intensity of this solution, $0.15 \mathrm{ml}$ of a 0.1 per cent solution of amylopectin sulfate was added, and a second nephelometric reading was made, not less than 10 minutes and not more than 30 minutes after the addition of the reagent. All nephelometric readings were carried out in either a Coleman Model 7 Photo-Nephelometer or in a Coleman Model 9 Nepho-Colorimeter. Commercial nephelos standards with $\mathrm{N}=75$ to $\mathrm{N}=78$ served as reference turbidities. ${ }^{1}$

1 Manufactured and calibrated by the Coleman Instrument Co., Inc. 
The data for $\beta$-lipoprotein thus obtained had the denomination of nephelometric indices expressed in nephelos units, and represent the increase in turbidity observed after addition of amylopectin sulfate to serum. These values are numerically identical with those obtained in a Fisher Nefluoro-Photometer, using as reference turbidities freshly prepared and stabilized barium sulfate suspensions, as described earlier (11). Multiplication of the nephelometric index by the empiric factor of 12.1 yields $\beta$-lipoprotein values in milligrams per $100 \mathrm{ml}$ of serum (11).

Source of serum samples. Serum from individuals without known disease was received from the following sources: Employee Relations Department of the Medical Division of the E. I. Du Pont de Nemours \& Company; Health Center of the International Ladies' Garment Workers' Union, Boston, Mass.; Medical Department of the New England Telephone and Telegraph Co.; Medical Department of the Socony Mobil Oil Company, Inc.; Lions Clubs of Brighton, Dedham, Foxboro, Medford, and Parkway (West Roxbury), Mass.; the Lexington Kiwanis Club; and Boston Chapter of the Alpha Kappa Alpha Sorority.

The following hospitals and institutions have contributed serum samples from patients: Boston City Hospital, New England Center Hospital, Holy Ghost Hospital in Cambridge, (all in Massachusetts), and the Memorial Hospital, New York.

All serum samples were shipped by air mail, or delivered locally by messenger. They were stored in a cool place at $2^{\circ}$ to $6^{\circ}$ for periods of time not exceeding 3 weeks. Freezing of the samples was avoided.

Characterization of amylopectin sulfate as the barium salt. The potency of each batch of amylopectin sulfate in producing turbidity with an excess of barium ions in acid medium was measured as follows: $0.3 \mathrm{ml}$ of a 1 per cent aqueous solution of the polyanion was added to a mixture of $1 \mathrm{ml}$ of 10 per cent barium acetate with 24 $\mathrm{ml} 0.2 \mathrm{~N} \mathrm{HCl}$, and the increase in turbidity was determined nephelometrically at least 10 minutes but not later than 15 minutes after the addition of the polyanion. This barium turbidity of the polyanion was expressed in nephelos units. Total serum cholesterol was determined by the method of Schoenheimer and Sperry (18).

Statistical analysis. Expressions and notations of Dixon and Massey's (19) textbook are used throughout this work. Statistical significance of the difference between the data of two groups has been expressed in $t$ values. At a 1 per cent level of significance, differences are considered to be highly significant when $t>2.6$ or $t<-2.6$ with more than 120 degrees of freedom. Since the comparison of each group was made with a normal sample of over 900 individuals, the degrees of freedom exceeded 120 in each case.

RESULTS

Testing of amylopectin sulfate for adequacy as a reagent. The quotients of barium turbidity (ob- tained in acid medium) to sulfur content (per cent $\mathrm{S}$ of the potassium salts) for 13 individual batches of corn amylopectin sulfate and for three batches of potato amylopectin sulfate are shown in Table I. These quotients are compared to the potency of each polyanion to produce a turbidity with serum $\beta$-lipoprotein at $\mathrm{pH} 8.6$; the latter value is expressed in per cent of the nephelometric index obtained with a reference polyanion (corn amylopectin sulfate, batch 11 ), and the same source of $\beta$-lipoprotein, i.e., the same serum sample. The following conclusions can be drawn from the data in Table I.

1) Most samples of corn amylopectin sulfate exhibit serum turbidity values ranging between 97.5 and 102.5 per cent of that of the reference polyanion. These batches may, thus, be considered to yield reproducible $\beta$-lipoprotein values, and to be adequate as a reagent.

2) All batches of amylopectin sulfate which exhibit serum turbidity values between 97.5 and 102.5 per cent of that of the reference polyanion show quotients of barium turbidity to sulfur content (bt/S quotients) ranging from 4.95 to 5.4 , while samples of amylopectin sulfate with lower serum turbidity values exhibit markedly lower bt/S quotients. The determination of the bt/S quotient of an amylopectin sulfate preparation appears to provide, therefore, a valuable criterion for the adequacy of the polyanion as a reagent for $\beta$-lipoprotein, wherever a reference preparation of amylopectin sulfate is not available.

3) While amylopectin sulfate preparations with low sulfur contents (10 per cent or less), obtained on purpose by incomplete sulfation (16), give low serum turbidity values, maximum turbidity can be reached with moderately sulfated corn amylopectin (13 per cent or more). No explanation is available, however, for the existence of an occasional batch of amylopectin sulfate with more than 13 per cent sulfur, but with a low serum turbidity (batch 15). The low bt/S quotient of such a batch easily allows its recognition.

4) The potency of corn amylopectin sulfate in producing a turbidity with serum $\beta$-lipoprotein is the same, irrespective of the crop of cornstarch used to obtain the amylopectin, and irrespective of the batch of amylopectin extracted from the cornstarch. 
TABLE I

Comparison of the serum turbidity of different batches of amylopectin sulfate by the use of the solubility of their barium salts

\begin{tabular}{|c|c|c|c|c|}
\hline $\begin{array}{l}\text { Source of amylo- } \\
\text { pectin sulfate }\end{array}$ & $\begin{array}{l}\text { Batch } \\
\text { no. }\end{array}$ & $\mathrm{S}$ & $\begin{array}{c}\text { Quotient of } \\
\text { barium } \\
\text { turbidity* } \\
\text { to per cent } \\
\text { sulfur }\end{array}$ & $\begin{array}{l}\text { Turbidity } \\
\text { with serum } \\
\text { at } \mathrm{pH} 8.6 \dagger\end{array}$ \\
\hline \multicolumn{5}{|c|}{$\%$} \\
\hline Cornstarch, crop A & $11 \ddagger$ & 16.67 & 5.1 & 100 \\
\hline Cornstarch, crop A & $12^{+}$ & 15.8 & 4.95 & 99.5 \\
\hline Cornstarch, crop A & 18 & 15.6 & 5.35 & 98.5 \\
\hline Cornstarch, crop B & 19 & 13.6 & 5.0 & 97.5 \\
\hline Cornstarch, crop B & 26 & 13.2 & 5.0 & 101.5 \\
\hline Cornstarch, crop B & 27 & 15.9 & 5.4 & 102.5 \\
\hline Cornstarch, crop B & 30 & 14.3 & 5.25 & 101 \\
\hline Cornstarch, crop B & 32 & 13.8 & 5.2 & 98.5 \\
\hline Cornstarch, crop B & 33 & 13.75 & 5.1 & 102 \\
\hline Cornstarch, crop B & 15 & 14.3 & 4.55 & 80 \\
\hline Cornstarch, crop B & 16 & $10.4 \S$ & 0.25 & 79 \\
\hline Cornstarch, crop B & 21 & $8.0 \S$ & 0.3 & 56 \\
\hline Potato starch $\|$ & 20 & 14.0 & 4.25 & 82 \\
\hline Potato starch\| & 22 & 17.5 & 3.55 & 94.5 \\
\hline Potato starch\| & 25 & 11.5 & 2.8 & 72 \\
\hline
\end{tabular}

* Definition of barium turbidity in acid medium, see text.

$\dagger$ Expressed in per cent of the nephelometric index observed with a reference polyanion (corn amylopectin sulfate, batch 11), using the same serum sample.

$\ddagger$ Reference polyanion, serum turbidity set at 100 .

$\$$ Low sulfur content, obtained on purpose by incomplete sulfation.

I| Potato amylopectin (Ramalin) obtained from Stein, Hall \& Co., N. Y.

5) Sulfated potato amylopectin yields generally lower serum turbidities than does corn amylopectin sulfate with corresponding sulfate content.

Normal population. The age distribution and the proportion of males and females in the normal population sample used in the present investiga- tion, as well as mean values for $\beta$-lipoprotein in the various age groups, are seen in Table II.

It is evident from the data in Table II that there is almost no difference between the mean $\beta$-lipoprotein values in normal males and females. Although the number of women with no known dis-

TABLE II

$\beta$-Lipoprotein in the normal population used in this study

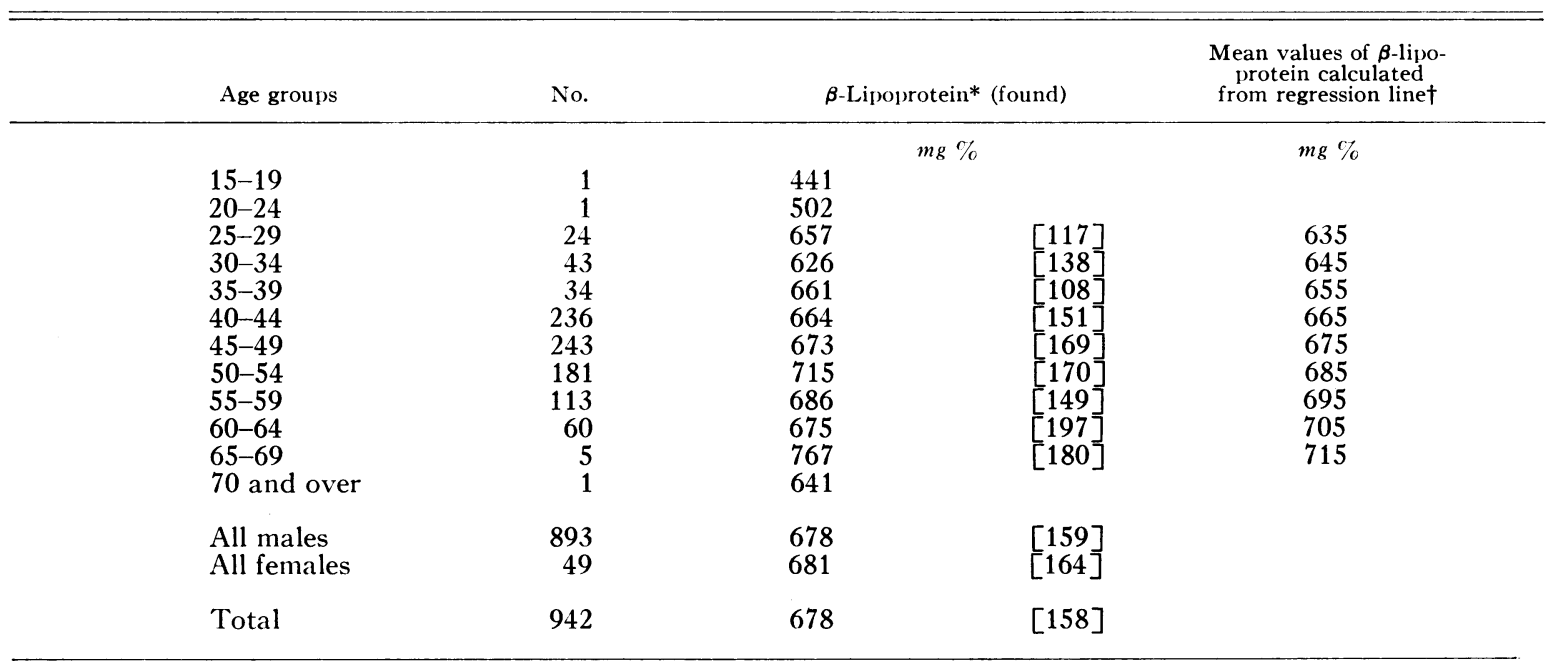

* Mean values; standard deviation in brackets.

+ See text. 
TABLE III

$\beta$-Lipoprotein values in cardiovascular disease

\begin{tabular}{|c|c|c|c|}
\hline Diagnosis & $\begin{array}{c}\text { Sample } \\
\text { no. }\end{array}$ & $\beta$-Lipoprotein* & $t$ Value \\
\hline Normals (see Table II) & 942 & $\begin{array}{c}m g \% \\
678[158]\end{array}$ & \\
\hline Myocardial infarcts (total) & 220 & $780[172]$ & 8.5 \\
\hline $\begin{array}{l}\text { Anterior } \\
\text { Anterior on anticoagulants } \ddagger \\
\text { Posterior } \\
\text { Posterior on anticoagulants } \ddagger \\
\text { Unclassified } \\
\text { Unclassified on anticoagulants } \ddagger\end{array}$ & $\begin{array}{r}57 \\
14 \\
38 \\
11 \\
99 \\
1\end{array}$ & $\begin{array}{l}790[162] \\
709[133] \\
772[161] \\
783[158] \\
785[188] \\
944\end{array}$ & \\
\hline Multiple myocardial infarcts & 11 & $841[225]$ & 3.4 \\
\hline Coronary artery disease (total) & 76 & $824[166]$ & 7.7 \\
\hline $\begin{array}{l}\text { Without anticoagulants } \\
\text { On anticoagulants } \ddagger\end{array}$ & $\begin{array}{r}72 \\
4\end{array}$ & $\begin{array}{l}822[167] \\
872[154]\end{array}$ & \\
\hline Arteriosclerotic heart disease (total) & 36 & $808[241]$ & 4.8 \\
\hline $\begin{array}{l}\text { Without anticoagulants } \\
\text { On anticoagulants } \ddagger\end{array}$ & $\begin{array}{r}29 \\
7\end{array}$ & $\begin{array}{l}826[256] \\
730[151]\end{array}$ & \\
\hline Miscellaneous cardiovascular diseases (total) & 15 & $668[150]$ & -0.24 \\
\hline $\begin{array}{l}\text { Hypertension } \\
\text { Cardiac disease, unclassified }\end{array}$ & $\begin{array}{l}6 \\
9\end{array}$ & $\begin{array}{l}678[120] \\
662[174]\end{array}$ & \\
\hline Total cardiovascular diseases & 358 & $790[182]$ & 11.0 \\
\hline
\end{tabular}

* Mean values, standard deviations in brackets.

$\dagger$ The $t$ value expresses the statistical significance of the difference in $\beta$-lipoprotein levels between each individual group and the. normals. A $t$ value of over 2.6 (or of less than -2.6 ) indicates that the difference is highly significant ( $\mathrm{p}<0.01$ )

$\ddagger$ Danilone, 2-phenyl-1,3-indanedione, Schieffelin \& Co. disease.

$\S$ Includes 1 Adams-Stokes syndrome with complete heart block, 1 enlarged heart, and 7 cases of unspecified heart

ease was small in comparison to the corresponding male population, the $t$ value of statistical significance for these two groups of normals is as low as $t=-0.21$. This indicates that the whole population sample is well suited for a normal control group in this study, in spite of the relatively small number of females it contains.

While the data at first sight seem to show that in the age groups above 25 years $\beta$-lipoprotein does not depend on age, closer observation indicates that $\beta$-lipoprotein in a few of the 5 -year age groups would significantly differ from the mean of the whole normal population, e.g., the 50 to 54 year age group exhibits a $t$ of 2.85 , and the 30 to 34 year age group a $t$ of -2.1 . This appears unlikely, however. On the other hand, when the relationship of age to $\beta$-lipoprotein levels is expressed by a regression line calculated from the mean values of Table II, this regression line, with the parameter $b=2.00$, shows that the theoretical mean values for $\beta$-lipoprotein gradually and slowly increase with age, and it leads to calculated values for each 5-year age group shown in the last column of Table II. These latter values agree well with the mean values found experimentally.

The differences in mean $\beta$-lipoprotein values between the normal control group and groups of patients with certain diseases were considerable ( $t$ greater than 3.7 or less than -3.7 ), as shown in the following four tables. It was not felt necessary, therefore, to take the age relationship into account, in particular since the normal population ranged in age from 25 to 70 years, with 89 per cent of the subjects being over 40 years of age. The normal control group, exhibiting a mean age of 45.3 years, thus resembled closely the various patient populations with respect to age distribution. Consequently, all $t$ values given in Tables III through VI were calculated on the basis of a mean $\beta$-lipoprotein value for the whole normal group, i.e., $678 \mathrm{mg}$ per $100 \mathrm{ml}$. 
TABI, IV

$\beta$-Lipoprotein in cerebrovascular disease

\begin{tabular}{|c|c|c|c|}
\hline Diagnosis & $\begin{array}{c}\text { Sample } \\
\text { no. }\end{array}$ & $\beta$-Lipoprotein* & $t$ Valuet \\
\hline Normals (see Table II) & 942 & $\begin{array}{l}m g \% \\
678[158]\end{array}$ & \\
\hline Cerebral thrombosis (total) & 132 & $764[203]$ & 5.6 \\
\hline $\begin{array}{l}\text { Without hypertension } \\
\text { With hypertension }\end{array}$ & $\begin{array}{l}97 \\
35\end{array}$ & $\begin{array}{l}737[203] \\
837[188]\end{array}$ & \\
\hline Cerebral hemorrhage (total) & 12 & $851[250]$ & 3.7 \\
\hline $\begin{array}{l}\text { Without hypertension } \\
\text { With hypertension }\end{array}$ & $\begin{array}{l}7 \\
5\end{array}$ & $\begin{array}{r}724[212] \\
1,030[190]\end{array}$ & \\
\hline Cerebrovascular accidents, unclassified (total) & 119 & $799[250]$ & 7.3 \\
\hline $\begin{array}{l}\text { Without hypertension } \\
\text { With hypertension }\end{array}$ & $\begin{array}{r}109 \\
10\end{array}$ & $\begin{array}{l}788[234] \\
916[384]\end{array}$ & \\
\hline Multiple cerebral thromboses (total) & .37 & $825[188]$ & 5.5 \\
\hline $\begin{array}{l}2 \text { Strokes } \\
2 \text { Strokes with hypertension } \\
3 \text { Strokes } \\
3 \text { Strokes with hypertension } \\
\text { More than } 3 \text { strokes } \\
\text { More than } 3 \text { strokes with hypertension }\end{array}$ & $\begin{array}{r}8 \\
2 \\
3 \\
1 \\
16 \\
7\end{array}$ & $\begin{array}{l}871[178] \\
876 \\
770[87] \\
759[ \\
830[241] \\
782[53]\end{array}$ & \\
\hline Miscellaneous cerebrovascular diseases (total) & 7 & $693[145]$ & 0.26 \\
\hline $\begin{array}{l}\text { Without hypertension } \ddagger \\
\text { With hypertension }\end{array}$ & $\begin{array}{l}5 \\
2\end{array}$ & $\begin{array}{l}697[166] \\
687\end{array}$ & \\
\hline Total cerebrovascular diseases & 307 & $787[223]$ & 9.4 \\
\hline
\end{tabular}

* Mean values, standard deviations in brackets.

$\dagger$ The $t$ value expresses the statistical significance of the difference of $\beta$-lipoprotein levels between each individual group and the normals. A $t$ value of over 2.6 or less than -2.6 indicates that the difference is highly significant $(\mathrm{p}<$ 0.01 ).

$\ddagger$ Includes 2 cases of generalized cerebral arteriosclerosis, 2 of cerebral vascular insufficiency, and 1 organic brain syndrome with severe arteriosclerosis.

TABLE $\mathrm{V}$

$\beta$-Lipoprotein in arteriosclerosis

\begin{tabular}{|c|c|c|c|}
\hline Diagnosis & $\begin{array}{c}\text { Sample } \\
\text { no. }\end{array}$ & $\beta$-Lipoprotein* & $t$ Valuef \\
\hline \multicolumn{4}{|c|}{$m g \%$} \\
\hline Normals (see Table II) & 942 & $678[158]$ & \\
\hline Cardiovascular disease (see Table III) & 358 & $790[182]$ & 11.0 \\
\hline Cerebrovascular disease (see Table IV) & 307 & $787[223]$ & 9.4 \\
\hline $\begin{array}{c}\text { Simultaneous cardiovascular and cere- } \\
\text { brovascular disease (total) }\end{array}$ & 63 & $803[194]$ & 6.0 \\
\hline $\begin{array}{l}\text { Unclassified } \\
\text { With hypertension } \\
\text { With coronary insufficiency } \\
\text { With myocardial infarcts }\end{array}$ & $\begin{array}{l}15 \\
21 \\
12 \\
15\end{array}$ & $\begin{array}{l}782[186] \\
823[218] \\
785[168] \\
813[202]\end{array}$ & \\
\hline Other arteriosclerotic syndromes (total) & 35 & $753[157]$ & 2.8 \\
\hline $\begin{array}{l}\text { Carotid artery thrombosis } \\
\text { Basilar artery insufficiency } \\
\text { Miscellaneous } \ddagger\end{array}$ & $\begin{array}{r}11 \\
18 \\
6\end{array}$ & $\begin{array}{l}830[154] \\
691[143] \\
800[149]\end{array}$ & \\
\hline Total of arteriosclerosis & 763 & $788[199]$ & 12.75 \\
\hline
\end{tabular}

* Mean values, standard deviations in brackets.

$\dagger$ The $t$ value expresses the statistical significance of the difference of $\beta$-lipoprotein levels between each individual group and the normals. A $t$ value of over 2.6 or of less than -2.6 indicates that the difference is highly significant ( $p$ $<0.01$ ).

$\ddagger$ Includes 1 Alzheimer's disease, 1 case of senility and 4 cases of general arteriosclerosis. 
$\beta$-Lipoprotein in arteriosclerosis. The data in Tables III to V show that the nephelometric procedure for $\beta$-lipoprotein is well qualified to demonstrate the increase in concentration of this serum protein in cardiovascular and cerebrovascular diseases, as has already been indicated in a preliminary communication (20). The elevated $t$ values are an expression of the high significance of these increases. In a total of 763 patients with various syndromes due to arteriosclerosis, the mean $\beta$-lipoprotein was elevated from the normal level of 678 to $788 \mathrm{mg}$ per $100 \mathrm{ml}$ with a $t$ value of 12.75 . The high standard deviations of the means of 158 and 199, respectively, characterize the large spread of the individual data. This indicates a considerable amount of overlapping between the values of normal subjects and those of patients.

It can also be seen from the data in Tables III

TABLE VI

$\beta$-Lipoprotein in diseases and conditions other than arteriosclerosis *

\begin{tabular}{|c|c|c|c|}
\hline Disease & $\begin{array}{c}\text { Sample } \\
\text { no. }\end{array}$ & $\beta$-Lipoprotein $\dagger$ & $t$ Value $\ddagger$ \\
\hline & & $m g \%$ & \\
\hline Normals (see Table II) & 942 & $678[158]$ & \\
\hline Kidney diseases (total) & 51 & $785[208]$ & 4.7 \\
\hline $\begin{array}{l}\text { Unclassified } \\
\text { Chronic pyelonephritis } \\
\text { Acute and chronic pyelonephritis } \\
\text { Acute glomerulonephritis } \\
\text { Chronic glomerulonephritis } \\
\text { With malignant hypertension } \\
\text { Gouty nephritis }\end{array}$ & $\begin{array}{r}12 \\
26 \\
3 \\
2 \\
6 \\
1 \\
1\end{array}$ & $\begin{aligned} & 685 {[173] } \\
& 790 {[231] } \\
& 857 {[223] } \\
& 909 {[279] } \\
& 828 {[99] } \\
& 1,118 \\
& 788\end{aligned}$ & \\
\hline Liver diseases (total) $\S$ & 21 & $808[237]$ & 3.7 \\
\hline Malignant diseases (total) & 91 & $709[178]$ & 1.8 \\
\hline $\begin{array}{l}\text { Solid tumors\| } \\
\text { Lymphomas } \| \\
\text { Leukemias** }\end{array}$ & $\begin{array}{l}64 \\
15 \\
12\end{array}$ & $\begin{array}{l}711[173] \\
750[203] \\
644[163]\end{array}$ & \\
\hline Hemorrhagic diseases $\dagger \dagger$ & 3 & $832[68]$ & 1.7 \\
\hline Arthritis & 9 & $650[235]$ & -0.52 \\
\hline Diabetes & 81 & $764[201]$ & 4.6 \\
\hline Neurological diseases (total) & 13 & $575[113]$ & -2.3 \\
\hline $\begin{array}{l}\text { Multiple sclerosis } \\
\text { Parkinson's disease } \\
\text { Miscellaneous } \ddagger\end{array}$ & $\begin{array}{l}4 \\
7 \\
2\end{array}$ & $\begin{array}{l}626[119] \\
567[111] \\
499\end{array}$ & \\
\hline Essential hypercholesterolemia & 29 & $974[262]$ & 9.7 \\
\hline Obesity & 9 & $764[201]$ & 1.85 \\
\hline Other diseases§§ & 14 & $686[157]$ & 0.20 \\
\hline
\end{tabular}

* Clinical findings on the patients whose lipoprotein data were compiled in this table did not indicate the presence of cerebrovascular or cardiovascular disease.

$\dagger$ Mean values, standard deviations in brackets.

¥ The $t$ value expresses the statistical significance of the difference of $\beta$-lipoprotein levels between each individual group and the normals. A $t$ value of over 2.6 or of less than -2.6 indicates that the difference is highly significant $(p<0.01)$

\$ Includes 9 cases of cirrhosis, 2 of infectious hepatitis, 7 cases of hepatitis (unclassified), and 3 cases of unspecified liver disease.

|| Fifteen carcinoma of the breast, 14 of the prostate, 8 of the lung, 5 of the colon, 5 of the stomach, 4 of the esophagus, 3 of the rectum, 3 of the cervix, 1 each of the tongue, throat, bladder and uterus, 1 melanoma, 1 hypernephroma, and 2 unspecified carcinomas.

T Seven cases with Hodgkin's disease, 4 lymphomas, 2 lymphosarcomas, and 2 multiple myelomas.

** Ten myelogenous and 2 lymphatic leukemias.

tt Three cases with anemia.

$\ddagger$ One case each with epilepsy and cerebral palsy.
$\S \S$ Three cases with psychoneurosis, 2 with lues, and 1 with each of the following conditions: infectious mononucleosis, tuberculosis, prostatic hypertrophy, aortic aneurysm, gall stones, retinitis, Pott's disease, Boeck's sarcoid, and fractured hip in an 84-year-old woman. 
TABLE VII

Correlation between total serum cholesterol and nephelometric $\beta$-lipoprotein

\begin{tabular}{|c|c|c|c|c|c|c|}
\hline & $\begin{array}{c}\text { High or } \\
\text { low } \\
\text { cholesterol* }\end{array}$ & No. & $\stackrel{\text { Mean }}{\bar{x}}$ & $\begin{array}{l}\text { Standard } \\
\text { deviation } \\
\mathrm{s}\end{array}$ & $\begin{array}{l}\text { Quotient } \\
\mathrm{s} / \overline{\mathrm{X}}\end{array}$ & $\begin{array}{l}\text { Correlation } \\
\text { coefficient }\end{array}$ \\
\hline Total cholesterol ( $m g \%)$ & $\begin{array}{l}\mathrm{A} \\
\mathrm{B}\end{array}$ & $\begin{array}{l}82 \\
13\end{array}$ & $\begin{array}{l}224 \\
361\end{array}$ & $\begin{array}{l}60.8 \\
92.1\end{array}$ & $\begin{array}{l}0.271 \\
0.255\end{array}$ & \\
\hline$\beta$-Lipoprotein ( $m g \%$ ) & $\begin{array}{l}\mathrm{A} \\
\mathrm{B}\end{array}$ & $\begin{array}{l}82 \\
13\end{array}$ & $\begin{array}{l}667 \\
923\end{array}$ & $\begin{array}{l}143 \\
207\end{array}$ & $\begin{array}{l}0.214 \\
0.224\end{array}$ & \\
\hline Ratio $\frac{\text { total cholesterol } \dagger}{\beta \text {-lipoprotein }}$ & $\begin{array}{l}A \\
B\end{array}$ & $\begin{array}{l}82 \\
13\end{array}$ & $\begin{array}{l}0.341 \\
0.395\end{array}$ & $\begin{array}{l}0.081 \\
0.0575\end{array}$ & $\begin{array}{l}0.237 \\
0.146\end{array}$ & $\begin{array}{l}0.61 \\
0.79\end{array}$ \\
\hline
\end{tabular}

* $\mathrm{A}=$ total cholesterol not exceeding $300 \mathrm{mg} \% ; \mathrm{B}=$ total cholesterol over $300 \mathrm{mg} \%$.

$\dagger$ This ratio has been calculated for the two measurements of each individual serum sample.

to $\mathrm{V}$ that the treatment of cardiovascular patients with such anticoagulants as Danilone, ${ }^{2}$ does not significantly reduce their serum $\beta$-lipoprotein. $\beta$-Lipoprotein levels were not found to be elevated in patients with uncomplicated hypertension, but in patients with hypertension associated with cerebrovascular disorders, $\beta$-lipoprotein was frequently higher than in patients with cerebrovascular disease alone.

$\beta$-Lipoprotein in other diseases. Significant increases in $\beta$-lipoprotein were shown not to be specific for patients with arteriosclerosis alone, but to occur also in a small number of totally unrelated conditions, namely, kidney diseases, liver diseases, and diabetes, as can be seen from the data in Table VI. On the other hand, patients with malignant diseases did not exhibit significant $\beta$-lipoprotein changes. Normal levels were also found in small numbers of patients with arthritis and with hemorrhagic, neurological and miscellaneous other diseases. The mean value of $\beta$-lipoprotein in obese persons appeared to be increased; this increase is not significant, however, due to the small number of subjects studied and to the high spread of the values, characterized by the high standard deviation.

Correlation between $\beta$-lipoprotein and total cholesterol. Elevated $\beta$-lipoprotein values in hypercholesterolemia, as seen in Table VI, were to be expected. At serum cholesterol values below 300 $\mathrm{mg}$ per $100 \mathrm{ml}$, however, there appears to be little relationship between the nephelometrically determined $\beta$-lipoprotein and the total cholesterol val-

2 Branch of 2-phenyl-1,3-indanedione, manufactured by Schieffelin \& Co. ues. Table VII shows results obtained with a population sample of 95 individuals chosen at random. Among these, 82 subjects had total cholesterol values not exceeding $300 \mathrm{mg}$ per 100 ml. This group contained 40 normal individuals, 17 patients with arteriosclerosis, 7 with neurological disorders, 6 with diabetes, 5 obese persons, 3 cases with psychoneurosis, 1 cancer patient, 1 arthritic, 1 individual with a fractured hip, and 1 patient with Pott's disease. It is evident from the data in Table VII that the quotient of standard deviation over mean value ( $\mathrm{s} / \overline{\mathrm{X}}$, see last column) is rather similar for the total cholesterol and for the $\beta$-lipoprotein values in this group, denoting an expected similarity of the sampling distributions of these two characteristics. If the $\beta$-lipoprotein concentrations were related to those of cholesterol, the ratios of these two measurements for each individual subject would tend to be constant, i.e., the quotient of standard deviation of the mean of these individual ratios over the mean of the ratios ( sixth column) would be much smaller than the corresponding $\mathrm{s} / \overline{\mathrm{X}}$ ratios for either total cholesterol or $\beta$-lipoprotein. The data in Table VII show that this is not the case, however. The independence of $\beta$-lipoprotein from total cholesterol is further illustrated by a low correlation coefficient of $R=0.61$, as well as by a very low rank correlation coefficient of $R_{\mathbf{s}}=0.34$, calculated from the experimental data. Measurements of total cholesterol and of $\beta$-lipoprotein would be interchangeable only if the correlation coefficients were 1 , or very close to unity. In the second group consisting of 13 individuals with hypercholesterolemia, the $s / \overline{\mathrm{X}}$ ratio is considerably lower 
than the corresponding ratios for both cholesterol and lipoprotein, while the correlation coefficient is significantly higher, denoting a higher degree of correlation between the two factors at high total cholesterol levels.

\section{DISCUSSION}

In evaluating the determination of serum $\beta$-lipoprotein obtained by the nephelometric method, one has to bear in mind that, on account of the marked heterogeneity of the so-called low density or $\beta$-lipoproteins, this procedure cannot be expected to exhibit a specificity for exactly the same spectrum of lipoproteins as other techniques which are based on entirely different properties of the lipoprotein, such as ultracentrifugal flotation or paper electrophoresis. While it has been demonstrated (11) that the present method measures only those lipoproteins which migrate as $\beta$-globulins upon electrophoresis of whole serum at $\mathrm{pH}$ 8.6 , and that all of the $\beta$-lipoproteins are involved in the precipitation with amylopectin sulfate at $\mathrm{pH}$ 8.6, an exact correlation between ultracentrifugal flotation rates of lipoproteins ( $\mathrm{S}_{\mathrm{f}}$-values) and their precipitation by amylopectin sulfate is rather difficult to establish. Nevertheless, it has been found that the flotation rate of $\beta$-lipoprotein fractions obtained at small amylopectin sulfate concentrations is lower than that of fractions precipitated at higher polyanion concentrations (21). It appears likely that $\beta$-lipoproteins with flotation rates between $S_{\mathrm{f}} 2$ and 12 with a peak at $S_{\mathrm{f}} 4$ have the highest affinity for amylopectin sulfate, and that the affinity slowly diminishes as the flotation rate increases, while chylomicrons are not precipitated at all.

The absence of a correlation between $\beta$-lipoprotein results obtained by the nephelometric method and data on lipoproteins of any of the routinely computed $\mathrm{S}_{\mathrm{f}}$-groups made it necessary to establish the clinical relevance of the new method in an independent manner. The data presented here show a highly significant statistical difference between the nephelometric $\beta$-lipoprotein values of normal individuals ranging from 25 to over 70 years of age and those of patients with cardiovascular disease, with cerebrovascular disease, with other arteriosclerotic syndromes, with diabetes, kidney and liver diseases, and, of course, with hypercholesterolemia.
It is evident, therefore, that the nephelometric method, because of its simplicity, rapidity and reproducibility, has proven its value as a clinical tool for the determination of serum $\beta$-lipoprotein. Although this method is not intended to replace the more intricate, costly and time consuming ultracentrifugal and electrophoretic techniques, the nephelometric method is considered to be of particular usefulness as an independent measurement of serum $\beta$-lipoprotein, especially for the purpose of screening great numbers of individuals, such as in large scale nutritional studies and in life insurance surveys of large populations, as well as for experimental work with small animals where the available amounts of serum are limited.

The comparison of nephelometric $\beta$-lipoprotein values with total cholesterol data showed that a certain correlation between these two factors exists. This was to be expected, since the latter is a component part of the molecule of the former. Nevertheless, it is evident that the correlation between these two serum constituents is so small that the determination of one in a given population sample will not lead to the same information as does the measurement of the other. The correlation becomes closer, however, as the cholesterol levels increase.

The use of corn amylopectin as a reagent for $\beta$-lipoprotein appears appropriate because its molecular weight is more controllable than that of any other macromolecular polysulfate esters which have been suggested as alternate reagents (1215). The elimination of the molecular weight of the polyanion as a variable thus assures a good reproducibility between the results of different laboratories.

In view of the extensive literature on elevated $\beta$-lipoprotein in arteriosclerosis and in certain other conditions (1-6), no comments on the present findings appear necessary.

However, in contrast to the present data, serum lipoprotein or serum lipid levels in patients with neoplastic diseases have been reported to be increased by some workers (22), and decreased by others (23). More work in this direction, in particular, on a larger patient population and with clear distinction between the different types of malignant diseases, will be necessary to draw final conclusions on the relationship of $\beta$-lipoprotein to neoplastic growth. 


\section{SUM MARY}

1. Serum $\beta$-lipoprotein was determined in over 2,000 individuals by the nephelometric method with amylopectin sulfate as reagent.

2. Since the molecular weight of polyanionic reagents for $\beta$-lipoprotein is known to influence the reaction markedly, the reproducibility of the results was ascertained by choosing corn amylopectin sulfate, the molecular weight of which is easily controllable, as the reagent.

3. A method for the standardization of the reagent was devised, based on the determination of its sulfur content and of the turbidity formed by the addition of barium ions to amylopectin sulfate in an acid medium. The results with different batches of the reagent were easily reproducible. The origin of the amylopectin from different crops of cornstarch, the extraction of the amylopectin from the starch, and the sulfation of amylopectin have no influence on the quality of the reagent.

4. A normal population of 942 individuals ranging from 25 to 70 years of age, with 89 per cent being over 40 years and with an average age of 45.3 years, exhibited a mean $\beta$-lipoprotein value of $678 \mathrm{mg}$ per $100 \mathrm{ml}$, with a standard deviation of 158. Mean $\beta$-lipoprotein values increased with age from $635 \mathrm{mg}$ per $100 \mathrm{ml}$ for the 25 to 29 year age group, to $715 \mathrm{mg}$ per $100 \mathrm{ml}$ for the 64 to 69 year age group.

5. In 763 individuals with arteriosclerosis, including 358 with cardiovascular disease, 307 with cerebrovascular disease, and 63 with the simultaneous occurrence of these two conditions, the mean lipoprotein level was elevated to $788 \mathrm{mg}$ per $100 \mathrm{ml}$. This increase is highly significant $(t=$ 12.75). Treatment of the cardiovascular patients with the anticoagulant, Danilone, does not significantly reduce their serum $\beta$-lipoprotein. $\mathrm{Pa}$ tients with hypertensive cerebrovascular disorders usually have higher $\beta$-lipoprotein levels than those with cerebrovascular disease without hypertension, while hypertension when occurring alone does not appear to be accompanied by changes of serum $\beta$-lipoprotein.

6. Increases in the concentrations of serum $\beta$-lipoprotein have also been observed in kidney diseases (mean $=785 \mathrm{mg}$ per $100 \mathrm{ml}$ in 51 cases, $t=4.7$ ), in liver diseases (mean $=808 \mathrm{mg}$ per $100 \mathrm{ml}$ in 21 cases, $t=3.7$ ), in diabetes (mean $=$
$764 \mathrm{mg}$ per $100 \mathrm{ml}$ in 81 cases, $t=4.6)$ and in hypercholesterolemia $($ mean $=974 \mathrm{mg}$ per 100 $\mathrm{ml}$ in 29 cases, $t=9.7$ ). No significant changes in serum $\beta$-lipoprotein were observed in malignant diseases (mean $=709 \mathrm{mg}$ per $100 \mathrm{ml}$ in 91 cases, $t=1.8$ ), or in limited numbers of patients with anemia, arthritis, neurological diseases, or obesity.

7. The correlation between total serum cholesterol and nephelometric $\beta$-lipoprotein is low; it is somewhat higher in patients with hypercholesterolemia.

\section{ACKNOWLEDGMENTS}

We are grateful to the following for supplying us with clinical information and serum samples from patients and normal subjects: Dr. Oscar Bodansky, Memorial Center for Cancer and Allied Diseases; Dr. Allan J. Fleming, Medical Director, E. I. du Pont de Nemours \& Company, Inc.; Dr. Martin M. Nothmann, New England Medical Center; Dr. H. A. Sinclaire, Clinical Director, Socony Mobil Oil Company, Inc.; Dr. George F. Wilkins, Medical Director, New England Telephone and Telegraph Co.; and to Drs. Stanley Alexander, Antonio Gonzaga, Milton Nicheman, H. W. Polchopek, John F. Simpson, Rui Soeiro, and Ian L. Thompson, past and present residents at Boston City Hospital.

\section{REFERENCES}

1. Gofman, J. W., Lindgren, F., Elliott, H., Mantz, W., Hewitt, J., Strisower, B., Herring, V., and Lyon, T. P. The role of lipids and lipoproteins in atherosclerosis. Science 1950, 111, 166.

2. Jones, H. B., Gofman, J. W., Lindgren, F. T., Lyon, T. P., Graham, D. M., Strisower, B., and Nichols, A. V. Lipoproteins in atherosclerosis. Amer. J. Med. 1951, 11, 358.

3. Gofman, J. W., Glazier, F., Tamplin, A., Strisower, B., and De Lalla, O. Lipoproteins, coronary heart disease, and atherosclerosis. Physiol. Rev. 1954, 34, 589.

4. Technical Group of the Committee on Lipoproteins and Atherosclerosis, and Committee on Lipoproteins and Atherosclerosis of the National Advisory Heart Council. Evaluation of serum lipoprotein and cholesterol measurements as predictors of clinical complications of atherosclerosis: Report of a cooperative study of lipoproteins and atherosclerosis. Circulation 1956, 14, 691.

5. Gofman, J. W. The clinical significance of serum lipoproteins in The Lipoproteins, Methods and Clinical Significance, F. Homburger and P. Bernfeld, Eds. Basel and New York, S. Karger, 1958, pp. $47-70$. 
6. Barr, D. P., Russ, E. M., and Eder, H. A. Protein-lipid relationships in human plasma. II. In atherosclerosis and related conditions. Amer. J. Med. 1951, 11, 480.

7. Bernfeld, $P$. Interaction of plasma proteins with polyelectrolytes. Fed. Proc. 1955, 14, 182.

8. Bernfeld, P., Donahue, V. M., and Berkowitz, M. E. Interaction of human serum $\beta$-lipoglobulin with polyanions. J. biol. Chem. 1957, 226, 51.

9. Bernfeld, P. A new method for the determination of $\beta$-lipoglobulin in The Lipoproteins, Methods and Clinical Significance, F. Homburger and P. Bernfeld, Eds. Basel and New York, S. Karger, 1958, pp. 24-36.

10. Bernfeld, P., and Nisselbaum, J. S. Reaction of human serum $\beta$-lipoglobulin with macromolecular polysulfate esters. Fed. Proc. 1956, 15, 220.

11. Bernfeld, P., Berkowitz, M. E., and Donahue, V. M. A simple nephelometric method for the determination of human serum beta-lipoprotein. J. clin. Invest. 1957, 36, 1363.

12. Burstein, M., and Samaille, J. Sur une nouvelle méthode de dosage des $\beta$-lipoprotéines sériques par l'héparine. C. R. Acad. Sci. (Paris) 1956, 243, 2185.

13. Burstein, M., and Samaille, J. Sur le taux des $\beta$-lipoprotéines sériques chez quelques espèces. Rev. Hémat. 1957, 12, 679.

14. Antoniades, H. N., Tullis, J. L., Sargeant, L. H., Pennell, R. B., and Oncley, J. L. A simple nephelometric test for beta lipoproteins of human serum. J. Lab. clin. Med. 1958, 51, 630.
15. Boyle, E., and Moore, R. V. A new precipitation method for estimating serum beta lipoproteins. J. Lab. clin. Med. 1959, 53, 272.

16. Bernfeld, P., Nisselbaum, J. S., Berkeley, B. J., and Hanson, R. W. The influence of chemical and physicochemical nature of macromolecular polyanions on their interaction with human serum $\beta$-lipoproteins. J. biol. Chem. 1960, 235, 2852.

17. Schoch, T. J. The fractionation of starch. Advanc. in Carbohyd. Chem. 1945, 1, 247.

18. Schoenheimer, R., and Sperry, W. M. A micromethod for the determination of free and combined cholesterol. J. biol. Chem. 1934, 106, 745.

19. Dixon, W. J., and Massey, F. J., Jr. Introduction to Statistical Analysis. New York, McGraw-Hill, 1957.

20. Bernfeld, P. Nephelometric $\beta$-lipoprotein determination in patients with arteriosclerosis (abstract). Circulation 1959, 20, 671.

21. Bernfeld, P. Chemical fractionation of $\beta$-lipoproteins. Abstracts of papers presented at the 136th meeting of the American Chemical Society in Atlantic City, N. J., 1959, 1C.

22. Peterman, M. L., Barclay, M., Escher, G., and Kaufman, R. Changes in the plasma lipoproteins in women with carcinoma of the breast in The Lipoproteins, Methods and Clinical Significance, F. Homburger and P. Bernfeld, Eds. Basel and New York, S. Karger, 1958, pp. 75-86.

23. Miettinen, M. Serum lipids and lipoproteins in cancer, leukaemia, and malignant lymphogranulomatosis. Ann. Med. intern. Fenn. 1957, 46, 103. 